\title{
Performance Objectives of the Tank Waste Remediation Systems Low-Level Waste Disposal Program
}

\author{
Performance Assessment Team
}

Date Published

August 24, 1994

\section{DISCLAIMER}

This report was prepared as an account of work sponsored by an agency of the United States Government. Neither the United States Government nor any agency thereof, nor any of their employees, makes any warranty, express or implied, or assumes any legal liability or responsibility for the accuracy, completeness, or usefulness of any information, apparatus, product, or process disclosed, or represents that its use would not infringe privately owned rights. Reference herein to any specific commercial product, process, or service by trade name, trademark, manufacturer, or otherwise does not necessarily constitute or imply its endorsement, recommendation, or favoring by the United States Government or any agency thereof. The views and opinions of authors expressed herein do not necessarily state or reflect those of the United States Government or any agency thereof.

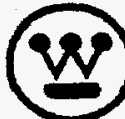

Hanford Operations and Engineering Contractor for the

U.S. Department of Energy under Contract DE-AC06-87RL10930 


\section{DISCLAIMER}

Portions of this document may be illegible in electronic image products. Images are produced from the best available original document. 
WHC-EP-0826, Rev. 1

\title{
PERFORIMANCE OBJECTIVES
}

\author{
of the
}

\section{TANK WASTE REMEDIATION SYSTEMS LOW-LEVEL WASTE DISPOSAL PROGRAM}

Performance Assessment Team

January 20, 1995 
WHC-EP-0826, Rev. 1

Table of Contents

1.0 OVERVIEW . . . . . . . . . . . . . . . . . . . 1

3.0 REgULATIONS AND OTHER PERFORMANCE ASSESSMENTS . . . . . . . . . 2

3.1 INTRODUCTION . . . . . . . . . . . . 2

3.2 PROTECTION OF THE GENERAL PUBLIC . . . . . . . . . 4

3.3 PROTECTION FOR WORKERS . . . . . . . . . . . . . . . . 4

3.4 PROTECTION OF THE INADVERTENT INTRUDER $\ldots \ldots \ldots$

3.5 PROTECTION OF GROUND WATER RESOURCES . . . . . . . . 5

3.6 PROTECTION OF SURFACE WATER RESOURCES . . . . . . . . . . 7

3.7 PROTECTION OF AIR RESOURCES ................ 8

4.0 PROGRAMMATIC REQUIREMENTS . . . . . . . . . . . . . . . 8

5.0 PUbliC INVLVVEMENT . . . . . . . . . . . . . . 8

Table 1.0 Radiological Performance objectives . . . . . . . . . 9

Appendix A. DOE Orders on Low-Level Waste Disposal . . . . . . . . . . A-1

1. 5820.2A (effective 9/26/88) . . . . . . . . . . . A-1

2. $5820.2 B$ (in draft) . . . . . . . . . . . . . A-1

3. RL 5820.2A (effective $11 / 23 / 1993$ ) ...........A-2

Appendix B . . . . . . . . . . . . . . . . B-1

Appendix C ..........................

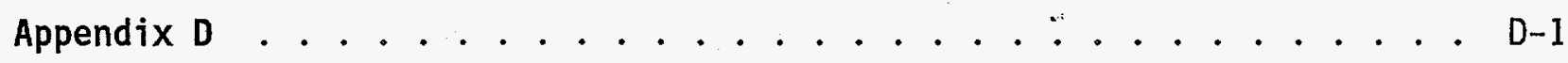


WHC-EP-0826, Rev. 1

\section{FOREWORD}

This document is a draft which is being released so that the Hanford stakeholders can help determine the performance objectives to be used in the assessment of long-term impact of the disposal of low-level waste from the Hanford tanks.

Thus this document assumes that there will be actions (such as public input) which at the time of release of this draft have, in fact, been minimal. We will use al1 input to help to improve the document. 
WHC-EP-0826, Rev. 1

\subsection{OVERVIEW}

The initial step in performing an assessment of the long-term impact of disposing of low-level waste from Hanford tanks is the creation of objective by which success or failure will be judged. These criteria, known as performance objectives, are based on

- DOE requirements,

$0 \quad$ programmic requirements, and

- public involvement.

The DOE requirements involved not only include the regulation directing the creation of the assessment, but also regulations that are directly and in directly cited in that regulation. In addition, other assessments have already been performed and "case law" has been established which can guide what is needed for a successful assessment.

As outlined below, perrformance objectives have determined. Radiological objectives are shown in Table I and chemical objectives are shown in Appendix D.

\subsection{INTRODUCTION}

Before low-level waste may be disposed of, a performance assessment must be written and then approved by the U.S. Department of Energy. The performance assessment is to determine whether "reasonable assurance" exists that the performance objectives of the disposal facility will be met. The DOE requirments for waste disposal $1^{1,2,3}$ require (see Appendix $A$ )

0 The protection of public health and safety; and

0 the protection of the environment.

Although quantitative limits are sometimes stated (for example, the all exposure pathways exposure limit is $25 \mathrm{mrem} / \mathrm{year}$ ), usually the requirements are stated in a general nature. Quantitative limits were established by

DOE Order 5820.2A, "Radioactive Waste Management," Chapter III, Section 3a, U.S. Department of Energy, Washington, D.C., September $26,1988$.

RLID 5820.2A, "Radioactive Waste Management," Chapter III, Section 3a, U.S. Department of Energy, Richland Operations Office, Richland, Washington, November 23, 1993.

DOE Order 5820.2B (draft), "Waste Management," Chapter IV, Section 3a, U.S. Department of Energy, Washington, D.C. DRAFT, January 14, 1994. 
WHC-EP-0826, Rev. 1

- Investigating all potentially applicable regulations as well as interpretations of the Peer Review Panel which DOE has established to review performance assessments,

o interacting with program management to establish their needs, and

o interacting with the public (i.e., the Hanford Advisory Board members; as well as affected Indian tribes) to understand the values of residents in the Pacific Northwest.

Note: [This is the first version of the performance objectives for general review. Therefore the contents are likely to change based on comments.]

\subsection{REGULATIONS AND OTHER PERFORMANCE ASSESSMENTS}

\subsection{INTRODUCTION}

A number of federal and state regulations are potentially applicable in determining how well the public health, safety and the environment must be protected. Appendix $B$ lists the regulations that were reviewed and judged potentially relevant to this proposed disposal action.

Other regulations and general environmental acts were not listed because

1. Requirements fall under other parts of the low-level waste project (i.e., the National Environmental Policy Act - NEPA);

2. requirements are for different environmental actions (for example, the Comprehensive Environment Response, Compensation, and Liability Act (ERCLA);

3. requirements deal with general environmental concerns (Endangered Species Act) and such concerns are thought to be adequately protected for the long-term by regulations presented here; or

4. they are only at a preliminary stage and are likely to change. Examples are the Radiation Site Cleanup Regulation (proposed 40 CFR 196) and Environmental Radiation Standards for Management and Disposal of LowLevel Waste (proposed 40 CFR 193) from the U.S. Environmental Protection Agency whose development will be closely followed.

This is not the first performance assessment concerning the disposal of low-level waste in the DOE complex. In fact, it is not the first one concerning Hanford wastes. Such prior assessments provide "case law" interpretations. Appendix $C$ list the other performance assessments in the DOE complex as well as their performance objectives. 
WHC-EP-0826, Rev. 1

\subsection{PROTECTION OF THE GENERAL PUBLIC}

Al1 regulations and past performance assessments consistently use an al1-pathways exposure limit of $25 \mathrm{mrem}(E D E) /$ years. Effective Dose Equivalent (EDE), was the method used during the 1980 s for setting dose limits. Prior to this method, a whole body dose method with limits for organs was used. Currently the method gaining favor is CDE, Cumulative Dose Equivalent. Although the numbers change slightly depending upon which method is used, the goal is to keep the risk to human health the same. In these performance objectives, EDE was selected because the regulations generally use this method. Thus, the performance objective for protection of the general public will be 25 mrem(EDE)/year.

There is little guidance on the interpretation for ALARA (as low as reasonably achievable), for this assessment, the requirements of Department of Energy, Richland Operations (DOE-RL) order 5820.2A (500 person-rem/year) are used.

Following the draft DOE order on waste management (DOE 5820.2B), the compliance time will be for 10,000 years, although the calculation will be carried out at least to the time of maximum impact. This is consistent with the time used in the Grout Performance Assessment ${ }^{4}$ as well as the

Environmental Impact Statement covering the disposal of these wastes. Using a time of compliance of 10,000 years is also consistent with the (Draft) Nuclear Regulatory Commission (NRC) branch technical position on performance assessment for low-level waste disposal facilities.

\subsection{PROTECTION FOR WORKERS}

As this is potentially a disposal action and protection to the general public is more stringent than to workers, no distinction in performance objectives will be made between workers and the general public. Protection for workers is also addressed through the Safety Analysis Report which will be created for the program.

C. T. Kincaid, J. A. Voogd, J. W. Shade, J. H. Westsik, Jr, G. A. Whyatt, M. D. Freshley, M. G. Piepho, K. A. Blanchard, K. Rhoads, and B. G. Lauzon, Performance Assessment of Grouted Double Shell Tank Waste Disposal at Hanford, WHC-SD-WM-EE-004, Rev. 0, Page 1.11, Westinghouse Hanford Company, Richland, Washington, October 1993 .

Branch Technical Position on Performance Assessment for Low-Level Disposal Facilities (draft). Low-Level Waste Management Branch, U.S. Nuclear Regulatory Commission, Washington, D.C., January, 1994. 
WHC-EP-0826, Rev. 1

\subsection{PROTECTION OF THE INADVERTENT INTRUDER}

The exposure limits for inadvertent intruder protection are consistent among the regulations and past performance assessments see appendices $B .2$ and C.2 respectively. The DOE-RL order allows a time of compliance of 500 years (that is, the time by which the predicted dose must be below objectives) if passive barriers and markers are used. The current DOE-HQ order makes no mention of the use of such barriers or markers. The draft revised DOE-HQ order, on the other hand, drops protection from inadvertent intrusion entirely. The Hanford Grout Performance Assessment, assuming the presence of passive barriers and markers, chose a compliance time of 500 years.

Since passive barriers and markers are planned for this disposal action, the precedent of the Grout Performance Assessment will be used. Therefore, protection of an inadvertent intruder shall be considered to be met if the 1.imits (500 mrem for a one-time exposure [that is, an acute exposure] and 100 $\mathrm{mrem} / \mathrm{year}$ for a continuous exposure) are met at 500 years after closure.

However, to display the doses as a function of time, the calculations will run from 100 years after the time of disposal to 10,000 years.

\subsection{PROTECTION OF GROUND WATER RESOURCES}

This is the most complicated requirement. Not only is it unclear how to measure protection but also the quantities being limited (decay rate and dose) are different in the different regulations. The protection of ground water is usually based on its intended use. Given the long time frames involved in a performance assessment, prediction of future ground water use is highly subjective.

In past performance assessments, protection has been based on a public drinking system of minimum size (i.e., on servicing about 25 people) located close to the disposal site ( 100 meters downstream from the disposal facility) and limiting the total exposure from all radionuclides for an individual to 4 mrem/year. The distance of 100 meters is also given in the RL order as well as the new draft DOE Order. Four (4) mrem/year was chosen as it corresponds to the risk-based limit (about $10^{-4}$ incremental lifetime fatal cancers) found in the National Primary Drinking Water. Regulations ${ }^{6}$ and for most of the radionuclides is more conservative (see Table B.3) than decay rate limits specified in the regulations. Washington, D.C., December 24, 1975. 
WHC-EP-0826, Rev. 1

The requirements for alpha emitters are the same in the state $^{7}$ and Federal regulations. The requirements of the State of Washington for beta emitters are based on a screening level previously used by Environmental Protection Agency (EPA). Thus the state requirements were intended to be easily verified in the field rather than to limit risk. A similar screening was performed by EPA, but the regulation now refers to risk. The current state screening level ensures that even for beta emitters emitting high energy gamma radiation, the dose limit will be met. However, in the case of low energy beta emitters, the State screening level is overly conservative by about a factor of 100 . For the radionuclides likely to be of importance in this performance assessment (most importantly ${ }^{99} \mathrm{TC}$ ), this high degree of conservatism exists in the State regulation. The differences between the State and Federal approaches will be more fully discussed in the Tank Waste Remediation System Environmental Impact Statement (TWRS EIS).

For this performance assessment, the risk value corresponding to $4 \mathrm{mrem} /$ year for beta and photon emitters is used as a performance objective. For comparison to heath-based hazardous waste regulations, a dose rate of 4 mrem/year over a period of 70 years corresponds to an incremental health risk of 0.0001 . However, if the record of decision of the TWRS EIS Differs from this, then that conclusion will be used.

To ensure compliance with the intent of federal and state regulations, it is proposed that the following limits apply to a well 100 meters downgradient from the disposal facility for a time of 10,000 years after closure (the same time of compliance as for protection of the general public):

alpha emitters

$$
\begin{aligned}
& \text { Ra-226: } \\
& \text { Ra-226 + Ra-228: } \\
& \text { sum (a)1 other alpha emitters): }
\end{aligned}
$$

beta and photon emitters

$\mathrm{H}-3$ :

Sr-90:

$20,000 \mathrm{pCi} / \mathrm{L}$ $8 \mathrm{pCi} / \mathrm{L}$

sum (a11 other beta and photon emitters):

The calculations will be performed to the time of maximum impact or to 10,000 years whichever is larger.

The hypothetical well will be sized to serve the minimum public drinking water system. Chemical concentration limits are given in Appendix D. 
WHC-EP-0826, Rev. 1

Although part of the siting criteria for a low level waste disposal facility is to avoid existing and probable future plumes of radioactive or hazardous substances, it is possible that such a plume could exist in the distant future when the waste is predicted to reach the ground water. Because such a plume would be inadvertent, it is not included in the analysis.

It should be noted that only the National Primary Drinking Water Regulations (40 CFR 141) are used. The National Secondary Drinking Water Standards are not used because the standards are stated only as goals.

\subsection{PROTECTION OF SURFACE WATER RESOURCES}

Surface water protection is almost as complicated as ground water protection. However, in this case the thrust of the Federal and State requirements ${ }^{8}$ is the same. The point of compliance will be where the ground water is predicted to reach the Columbia River. The concentrations in the ground water should meet all of the following:

alpha emitters

$\mathrm{Ra}-226+\mathrm{Ra}-228:$

sum (al1 other alpha emitters):
$0.3 \mathrm{pCi} / \mathrm{L}$ $15 \mathrm{pCi} / \mathrm{L}$

beta and photon emitters

$\mathrm{H}-3$ :

Sr-90:

$20,000 \mathrm{pCi} / \mathrm{L}$

$3 \mathrm{pCi} / \mathrm{L}$

sum (a11 other beta and photon emitters):

$1.0 \mathrm{mrem} /$ year

The value of 1.0 mrem/year (one-quarter of the EPA drinking water standard) is used because the State of Washington regulation uses the minimum of the EPA drinking water standard and explicit limits in a table contained in the regulation. For the major radionuclides of interest, the limits in the table are within a factor of three of the drinking water standard. Thus the factor of four is conservative. Whether just the federal drinking water standard should be used will be addressed in the TWRS EIS.

Chemical concentration limits are given in Appendix $D$.

Following the draft DOE order on waste management, the compliance time will be for 10,000 years, although the calculation will be carried out to the time of maximum impact, if the peak occurs afer 10,000 years

Because the protection of ground water and of surface water are both based on the drinking water standard and because of the large distance from 
WHC-EP-0826, Rev. 1

the disposal facility to the Columbia River, if the protection objective for ground water is met, the protection objective for surface water will be met.

\subsection{PROTECTION OF AIR RESOURCES}

Air emissions limits are taken from the National Emissions Standards (40 CFR 61) (10 $^{910}$ as they are more restrictive than the requirements of the state of Washington. Thus emissions (except radon) are limited to $10 \mathrm{mrem} / \mathrm{year}$ with radon emissions 1 imited to $20 \mathrm{pCi} / \mathrm{m}^{2} \mathrm{~s}$.

\subsection{PROGRAMMATIC REQUIREMENTS}

The TWRS Low-Leve1 Waste Program has mandated that all wastes to be disposed of and/or stored in the facility shall meet NRC Class C concentration 1 imits's. In addition, the glass waste form will meet RCRA concentration limits. Appendix B lists these limits in the glass waste form.

\subsection{PUBLIC INVOLVEMENT}

It is important that Hanford stakeholders have a chance to affect the performance objectives of this disposal action. The summary ${ }^{12}$ was sent to each member and alternate of the Hanford Advisory Board as well as to selected Hanford employees and to selected members of the Department of Energy's Peer Review Panel and Performance Assessment Task Team. Copies of this full document were sent to all who requested it.

40 CFR 61, Subpart H, "National Emission Standards for Emissions of Radionuclides Other than Radon from Department of Energy Facilities," Section 92, U. S. Environmental Protection Agency, Washington, D.C., December 15, 1989.

1040 CFR 61, Subpart Q, National Emission Standards for Radon Emissions from Department of Energy Facilities," Section 192, U.S. Environmental Protection Agency, Washington, D.C., December 15, 1989.

1110 CFR 61, "Licensing Requirements for the Land Disposal of Radioactive Waste," Section 55, U.S. Nuclear Regulatory Commission, Washington, D.C., December 27, 1982 as amended May 25, 1989.

12 "Overview of the Performance Objectives and Scenarios of the TWRS Low-Level Waste Disposal Program", WHC-EP-0827, Rev. 0, Westinghouse Hanford Company, Richland, Washington, October 13, 1994. 
WHC-EP-0826, ReV. 1

All comments received have been documented. These comments as well as the responses to them are available.

Comments on this version of the document should be sent to

George F. Williamson

Westinghouse Hanford Company

Mail Stop HO-36

PO Box 1970

Richland, Washington 99352 
WHC-EP-0826, Rev. 1

\section{Table 1.0 Radiological Performance Objectives}

Protection of General Public and Workers:

a]1-pathways:

$25 \mathrm{mrem} /$ year

ALARA (a11 pathways):

500 persons - rem/year

(evaluated for 10,000 years, but calculated to the time of peak dose or 10,000 years, whichever is longer)

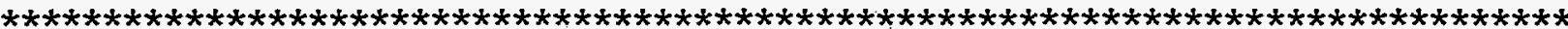

Inadvertent Intruder:

acute exposure:

500 mrem

continuous exposure:

$100 \mathrm{mrem} /$ year

(evaluated at 500 years)

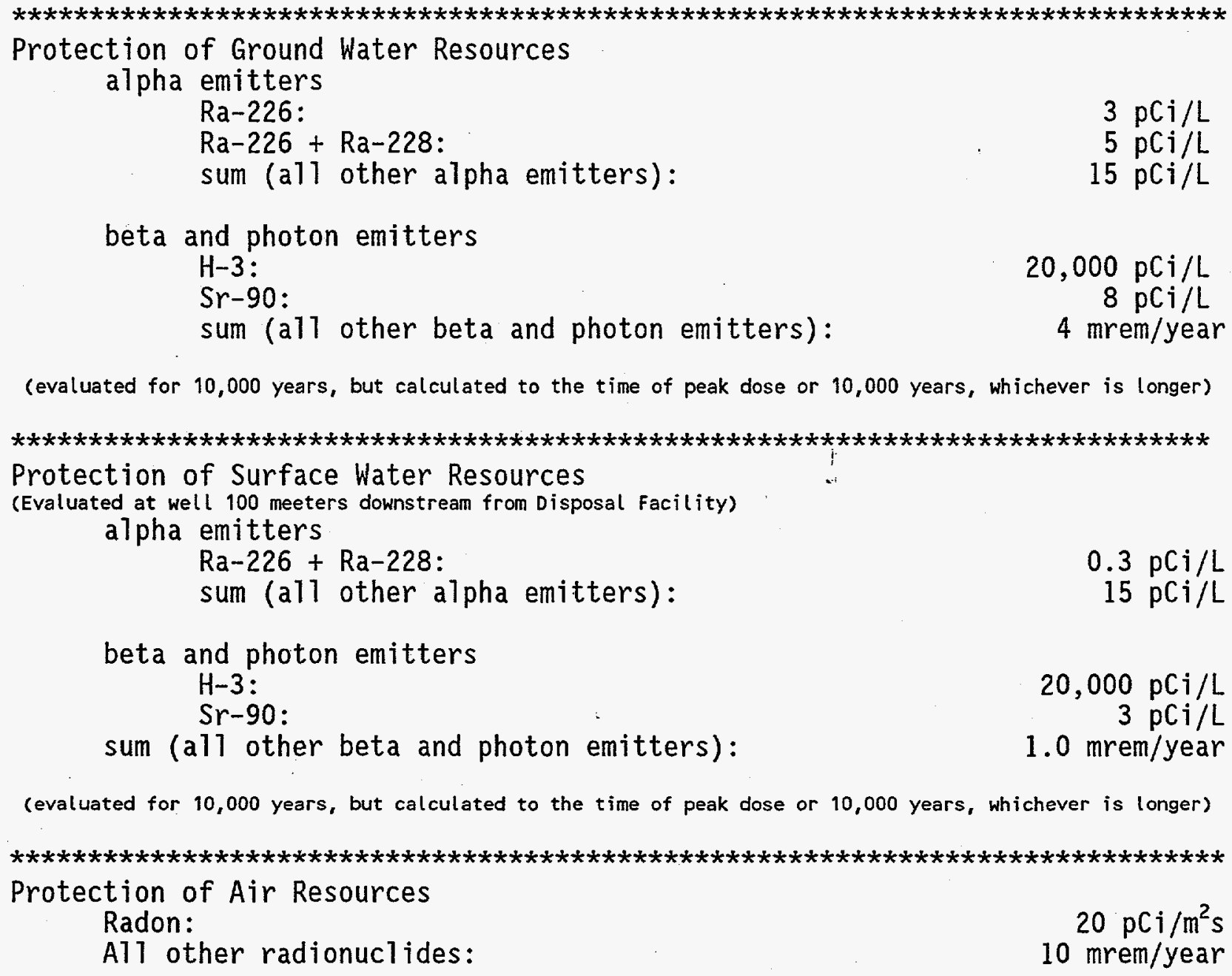

$20,000 \mathrm{pCi} / \mathrm{L}$ $8 \mathrm{pCi} / \mathrm{L}$

$4 \mathrm{mrem} /$ year

(evaluated for 10,000 years, but calculated to the time of peak dose or 10,000 years, whichever is longer)

beta and photon emitters

$\mathrm{H}-3$ :

Sr-90:

sum (a11 other beta and photon emitters):

$20,000 \mathrm{pCi} / \mathrm{L}$

$3 \mathrm{pCi} / \mathrm{L}$

$1.0 \mathrm{mrem} /$ year

(evaluated for 10,000 years, but calculated to the time of peak dose or 10,000 years, whichever is longer)

$\begin{array}{lr}* * * * * * * * * * * * * * * * * * * * * * * * * * * * * * * * * * * * * * * * * * * * * * * * * * * * * * * * * * * * * * * * * * * * * * * * * * * * * * \\ \text { Protection of Air Resources } & 20 \mathrm{pCi} / \mathrm{m}^{2} \mathrm{~s} \\ \text { Radon: } & 10 \mathrm{mrem} / \mathrm{year} \\ \text { All other radionuclides: } & \end{array}$

(evaluated for 10,000 years, but calculated to the time of peak dose or 10,000 years, whichever is longer)

Appendix A. DOE Orders on Low-Level Waste Disposal 
WHC-EP-0826, Rev. 1

\section{1. $5820.2 A$ (effective $9 / 26 / 88$ )}

This is the DOE Order currently governing the disposal of lowlevel waste $(5820.2 A)^{13}$. Chapter III, section 3 a states that the objectives are to

"1) Protect public health and safety in accordance with standards specified in applicable EH Orders and other DOE orders.

2) Assure that external exposure to the waste and concentrations of radioactive material which may be released into surface water, ground water, soil, plants, and animals results in effective dose equivalent that does not exceed $25 \mathrm{mrem} / \mathrm{yr}$ to any member of the public. Releases to the atmosphere shall meet the requirements of 40 CFR 61 . Reasonable effort should be made to maintain releases of radioactivity in effluents to the general environment as low as is reasonable achievable.

3) Assure that the committed effective dose equivalents received by individuals who inadvertently may intrude into the facility after the loss of active institutional control (100 years) will not exceed 100 mrem/year for continuous exposure or 500 mrem for a single acute exposure.

4) Protect ground water resources, consistent with Federal, State, and local requirements."

\section{5820.2B (in draft)}

This draft (DOE 5820.2B) ${ }^{14}$ is intended to revise the current order. Chapter IV, section $4 a(2)$ states the objectives are to

"1) Protect the public health and safety in accordance with DOE 5400.5 and applicable Federal, State, and local requirements;

2) Protect worker safety in accordance with DOE 5480.11 and applicable Federal, State, and local requirements;

3) Ensure the protection of the environment in accordance with DOE 5400.1 and applicable Federal, State, and local requirements;

4) Given the assumptions of reasonable foreseeable natural phenomena, and protection of doses to hypothetical individuals having standard

DOE Order 5820-2A, "Radioactive Waste Management," Chapter III, Section 3a, U.S. Department of Energy, Washington, D.C., September 26, 1988. U.S. Department of Energy, Washington D.C., DRAFT, January 14, 1994. 


$$
\text { WHC-EP-0826, Rev. } 1
$$

physiological characteristics, provide reasonable assurance that the combined releases to the atmosphere shall meet the requirements of 40 CFR 61 ; and

5) Ensure that all low-level radioactive waste management facilities are designed, constructed, and closed to maintain radiation exposures to workers and members of the general public as low as reasonably achievable."

In addition this sections requires

"1) Disposal facilities shall be designed, operated, and closed, and controlled after closure to provide reasonable assurance that exposures to individual members outside of the buffer zone shall not exceed an effective dose equivalent of 25 mrem $(0.25 \mathrm{mSv})$ per year through all exposure pathways, excluding dose from radon and its decay products. For releases directly to the atmosphere, the annual effective dose equivalent shall not exceed $10 \mathrm{mrem}(0.1 \mathrm{mSv})$, excluding dose from radon and its decay products, subject to any apportionment reduction required to meet the requirement of 40 CFR 61. Compliance with the dose objectives shall be demonstrated for a minimum period of 10,000 years after facility closure.

\section{RL 5820.2A (effective 11/23/1993)}

This directive ${ }^{15}$ from the Richland Operations office supplements DOE Order 5820.2A and has as performance objectives (Chapter III, 3a):

"1) General Public Protection. Disposal systems shall be designed to ensure that exposure to any member of the public that results from disposal of solid LLW [low-level waste] shall not exceed $25 \mathrm{mrem} / \mathrm{yr}$ Effective Dose Equivalent (EDE) through al1 exposure pathways for at least 1,000 years after disposal. The point of compliance shall be no further from the edge of the waste than the Hanford Site boundary during the period of active institutional control. After the active institutional control period (assumed to be no more than 100 years) the point of compliance shall be not more than 100 meters from the edge of the disposal site.

2) Groundwater Protection. Disposal systems shall be designed to meet the Clean Water Act and the Safe Drinking Water Act as well as ensure that disposal of LLW after 09-28-88 does not result in concentrations of radionuclides (above existing levels) in groundwater exceeding those corresponding to an EDE of $4 \mathrm{mrem} / \mathrm{yr}$ to any person who might drink 2 liters per day of water from a well drilled into the aquifer, for at $3 a$, U.S. Department of Energy, Richland Operations Office, Richland, Washington, November 23, 1993. 
WHC-EP-0826, Rev. 1

least 1,000 years after disposal. The point of compliance shall be no further than 100 meters from the edge of the waste.

3) ALARA (Long-Term Protection). Reasonable effort shall be made to design the disposal system in such a way that potential exposures are ALARA [as low as reasonably achievable] for all times up to the year of maximum exposure. If the predicted population exposure is less than 500 person-rem/yr in the year of maximum exposure, the ALARA requirement is defined to have been complied with.

4) Intruder Protection. Disposal closure systems shall be designed to ensure that exposure to individuals who inadvertently intrude into the closed facility after the active institutional control period shall not exceed $100 \mathrm{mrem} / \mathrm{yr}$ for continuous exposure, or $500 \mathrm{mrem}$ for a single acute exposure. For wastes that remain hazardous to inadvertent intruders beyond 100 years, passive controls (e.g. appropriate markers and barrier systems) shall be incorporated to provide reasonab7e assurance that inadvertent intruders will be warned and deterred from disturbing the site for up to 500 years.

5) Mixed-Waste Regulations. Disposal systems shall be designed to meet the applicable requirements of 40 CFR 264 and 265, and WAC 173-303 for the disposal of LLW-MW [low-level waste-mixed waste]."

In addition, the directive requires

"1) The assumptions, conceptual models, and computer codes used to prepare performance assessments for the Hanford Site LLW disposal sites shall be consistent to the extent practical. As a minimum, the following elements shall be considered for consistency:
a) Climate changes;
b) Generic intruder scenarios;
c) Vadose zone flow and transport models and codes;
d) Groundwater flow and transport models and codes; and
e) Dose-to-man models and codes.

2) All dose calculations shall be approved by the Hanford Site environmental dose overview panel.

3) The assumptions used in performance assessments shall be defensible and the basis for each assumption shall be documented." 
WHC-EP-0826, Rev. 1

Appendix B

Table B.1 List of Relevant Regulations

\begin{tabular}{||l|l|}
\hline Regulation & Comment \\
\hline $\begin{array}{l}\text { Radioactive Waste Management (DOE } \\
\text { Order 5820.2A) }\end{array}$ & $\begin{array}{l}\text { Current DOE order covering disposal } \\
\text { of low-level waste }\end{array}$ \\
\hline $\begin{array}{l}\text { Radioactive Waste Management (RLID } \\
5820.2 A)^{17}\end{array}$ & $\begin{array}{l}\text { Current implementing local directive } \\
\text { for disposal of low-level waste at } \\
\text { Hanford }\end{array}$ \\
\hline $\begin{array}{l}\text { Waste Management (DOE 5820.2B- } \\
\text { draft) }\end{array}$ & Draft revision of DOE order 5820.2A \\
\hline $\begin{array}{l}\text { Licensing Requirements for Land } \\
\text { Disposal of Radioactive Wastes } \\
\text { (10 CFR 61) }\end{array}$ & $\begin{array}{l}\text { Requirements of the Nuclear } \\
\text { Regulatory Commission for the land } \\
\text { disposal of low-level radioactive } \\
\text { waste }\end{array}$ \\
\hline $\begin{array}{l}\text { Radioactive Waste - } \\
\text { Licensing and Disposal (WAC } \\
246-250)^{20}\end{array}$ & $\begin{array}{l}\text { Sets requirements for disposal of } \\
\text { low-leve1 radioactive } \\
\text { wastes in the state of Washington }\end{array}$ \\
\hline
\end{tabular}

DOE Order 5820.2A, "Radioactive Waste Management," Chapter III, Section 3a, U.S. Department of Energy, Washington, D.C., September 26, 1988.

RLID 5820.2A, "Radioactive Waste Management, " Chapter III, Section 3a, U.S. Department of Energy, Richland Operations Office, Richland, Washington, November 23, 1993.

18 DOE Order 5820.2B, "Waste Management, " Chapter IV, Section 3a, U.S. Department of Energy, Richland Operations Office, Richland, Washington, November 23, 1993.

1910 CFR 61, "Licensing Requirements for the Land Disposal of Radioactive Waste," Section 41, U.S. Nuclear Regulatory Commission, Washington, D.C., December 27, 1982 as amended May 25, 1989.

WAC 246-250, "Radioactive Waste - Licensing Land Disposal," Section 170, Washington State Department of Health, OTympia, Washington, December 11, 1986. 


\begin{tabular}{|c|c|}
\hline Regulation & Comment \\
\hline $\begin{array}{l}\text { General Environmental Protection } \\
\text { Program (DOE Order } 5400.1 \text { ) }\end{array}$ & $\begin{array}{l}\text { Lists executive orders, } 1 \text { aws, and } \\
\text { regulations which DOE actions must } \\
\text { meet }\end{array}$ \\
\hline $\begin{array}{l}\text { Hazardous and Radioactive Mixed } \\
\text { Waste Program (DOE Order } 5400.3 \text { ) }\end{array}$ & $\begin{array}{l}\text { Outlines philosophy for waste } \\
\text { containing radionuclides and } \\
\text { hazardous chemicals }\end{array}$ \\
\hline $\begin{array}{l}\text { Radiation Protection of the Public } \\
\text { and the Environment (DOE Order } \\
5400.5 \text { ) }\end{array}$ & $\begin{array}{l}\text { Provides exposure limits for general } \\
\text { activities }\end{array}$ \\
\hline $\begin{array}{l}\text { Environmental Protection, Safety, } \\
\text { and Health Standards (DOE Order } \\
5480.4 \text { ) }\end{array}$ & $\begin{array}{l}\text { Lists reference environment } \\
\text { protection, safety, and health } \\
\text { standards }\end{array}$ \\
\hline $\begin{array}{l}\text { Radiation Protection for Occupation } \\
\text { Workers (DOE Order } 5480.11 \text { ) }\end{array}$ & Provides dose limits for workers \\
\hline $\begin{array}{l}\text { Environmental Protection, Safety, } \\
\text { and Hea] th Protection Standards For } \\
\mathrm{RL}(\mathrm{RL} 5480.4 \mathrm{~B})\end{array}$ & $\begin{array}{l}\text { Supplements DOE Order } 5480.4 \text {. } \\
\text { Includes state and local } \\
\text { regulations. }\end{array}$ \\
\hline $\begin{array}{l}\text { Radiation Protection Standards } \\
\text { (WAC 246-221) }\end{array}$ & $\begin{array}{l}\text { Sets radiation protection standards } \\
\text { for the state of Washington }\end{array}$ \\
\hline $\begin{array}{l}\text { National Emission Standards for } \\
\text { Emissions of Radionuclides other } \\
\text { than Radon from Department of } \\
\text { Energy Facilities ( } 40 \text { CFR } 61.92 \text { ) }\end{array}$ & $\begin{array}{l}\text { Establishes maximum exposure to } \\
\text { public via air pathway for non-radon } \\
\text { radionuclides }\end{array}$ \\
\hline $\begin{array}{l}\text { National Emission Standards for } \\
\text { Radon Emissions from Department of. } \\
\text { Energy Facilities (40 CFR 61.192) }\end{array}$ & $\begin{array}{l}\text { Establishes maximum exposure to } \\
\text { public of Ra-222 via air pathway }\end{array}$ \\
\hline $\begin{array}{l}\text { Ambient Air Quality Standards and } \\
\text { Emission Limits for Radionuclides } \\
\text { (WAC 173-480) }\end{array}$ & $\begin{array}{l}\text { Sets emission standards into air for } \\
\text { radionuclides in the state of } \\
\text { Washington }\end{array}$ \\
\hline $\begin{array}{l}\text { Radiation Protection - Air emissions } \\
\text { (WAC 246-247) }\end{array}$ & $\begin{array}{l}\text { Sets radioactive air emissions } \\
\text { standard }\end{array}$ \\
\hline $\begin{array}{l}\text { National Primary Drinking Water } \\
\text { Regulations ( } 40 \text { CFR 141) }\end{array}$ & Sets drinking water standards \\
\hline
\end{tabular}

DOE Order 5400.1, "General Environmental Protection Program", U.S. Department of Energy, Washington, D.C., June 29, 1990.

40 CFR 141, "National Primary Drink Water Regulations," Section 15 and 16, U.S. Environmental Protection Agency, Washington, D.C., December 24, 1975. 
WHC-EP-0826, Rev. 1

\begin{tabular}{||l|l||}
\hline Regulation & Comment \\
\hline $\begin{array}{l}\text { Water Qual ity Standards for Ground } \\
\text { Waters of the State of Washington } \\
\text { (WAC 173-200) }\end{array}$ & $\begin{array}{l}\text { Sets standard for ground waters in } \\
\text { the state of Washington }\end{array}$ \\
\hline $\begin{array}{l}\text { Water Qual ity Standards for Surface } \\
\text { Waters of the State of Washington } \\
\text { WAC 173-201A) }\end{array}$ & $\begin{array}{l}\text { Set standards for surface waters in } \\
\text { the state of Washington }\end{array}$ \\
\hline $\begin{array}{l}\text { Identification and Listing of } \\
\text { Hazardous Waste (40 CFR 261) }\end{array}$ & $\begin{array}{l}\text { Establishes which wastes are subject } \\
\text { to RCRA }\end{array}$ \\
\hline $\begin{array}{l}\text { Land Disposal Restrictions } \\
\text { (40 CFR 268) }\end{array}$ & $\begin{array}{l}\text { Limits disposal options for } \\
\text { hazardous wastes }\end{array}$ \\
\hline $\begin{array}{l}\text { Dangerous Waste Regulations } \\
\text { (WAC 173-303) }\end{array}$ & $\begin{array}{l}\text { Implements RCRA in the state of } \\
\text { Washington }\end{array}$ \\
\hline
\end{tabular}

WAC 173-200, Water Quality Standards for Ground Waters of the State of Washington, Section 40, Washington State Department of Ecology, OTympia, Washington, December I, 1990.

WAC 173-201A, Water Quality Standards for Surface Waters of the State of Washington, Washington State Department of Ecology, 01 ympia, Washington, December 22, 1992.

40 CFR 261, "Identification and Listing of Hazardous Waste," U.S. Protection Agency, Washington, D.C., May 19, 1980.

WAC 173-303, "Dangerous Waste Regulations," Washington State Department of Ecology, 01ympia, Washington, January, 1989. 
WHC-EP-0826, Rev. 1

Table B.2 Requirements of Relevant Regulations

General Radioactive Waste Regulations

DOE 5820.2a: (III, 3a) ${ }^{28}$

all pathways:

$25 \mathrm{mrem} /$ year

ALARA

intruder (100 years):

$100 \mathrm{mrem} /$ year (continuous)

intruder (100 years):

500 mrem (single event)

DOE $5820.2 b(\text { IV, } 3 b)^{29}$

a11 pathways $(10,000$ years $)$ :

$25 \mathrm{mrem} /$ year

RL 5820.2a (III, 3a) 30

a11 pathways ( 1,000 years):

$25 \mathrm{mrem} /$ year

intruder $(100 / 500$ years $)$ :

intruder $(100 / 500$ years $)$ :

drinking water (2 L/day from $100 \mathrm{~m}$ well):

ALARA

$100 \mathrm{mrem} /$ year (continuous) 500 mrem (single event)

$4 \mathrm{mrem} /$ year

$<500$ person-rems/year

10 CFR $61.41^{31}$

all pathways (whole body):

a11 pathways (thyroid):

$25 \mathrm{mrem} /$ year

all pathways (other organs):

$75 \mathrm{mrem} /$ year Only Class C disposal

DOE Order 5820.2A, "Radioactive Waste Management," Chapter III, Section 3a, U.S. Department of Energy, Washington, D.C., September 26, 1988.

DOE order 5820.2B, "Waste Management," Chapter IV, Section 3a, U.S. Department of Energy, Washington D.C., DRAFT, January 14, 1994.

RLID 5820.2A, "Radioactive Waste Management," Chapter III, Section 3a, U.S. Department of Energy, Richland Operations Office, Richland, Washington, November 23, 1993.

10 CFR 61, "Licensing Requirements for the Land Disposal of Radioactive Waste," Section 41, U.S. Nuclear Regul atory Commission, Washington, D.C., December 27, 1982 as amended May 25, 1989. 
WAC $246-250-170^{32}$

a11 pathways (whole body):

$25 \mathrm{mrem} /$ year

all pathways (thyroid):

$75 \mathrm{mrem} /$ year

a11 pathways (other organs):

$25 \mathrm{mrem} /$ year

only class C disposal

\section{General Protection}

DOE Order 5400.11 (Section 9$)^{33}$

a) 1 pathways (occupational worker):

all pathways (unborn child):

all pathways (general public):

$5000 \mathrm{mrem} /$ year

500 mrem

$100 \mathrm{mrem} /$ year

WAC $246-221-040^{34}$

al1 pathways (restricted area): $\quad 1250 \mathrm{mrem} / \mathrm{calendar}$ quarter

WAC $246-221-060^{35}$

al1 pathways (unrestricted area):

$2 \mathrm{mrem} / \mathrm{hour}$

al1 pathways (unrestricted area):

$100 \mathrm{mrem} /$ week

a11 pathways (unrestricted area) [prior approval]: $500 \mathrm{mrem} / \mathrm{year}$

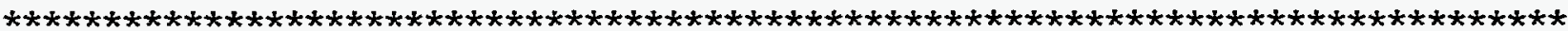

Air and Water Regulations

WAC $246-221-290^{36}$

air and water concentration limits: see table in regulations

WAC 246-250, "Radioactive Waste - Licensing Land Disposal,"

Section 170, Washington State Department of Health, Olympia, Washington, December 11, 1986.

DOE Order 5480.11, "Radiation Protection for Occupational

Workers," U.S. Department of Energy, Washington, D.C., June 17, 1992.

WAC 246-221, "Radiation Protection Standards," Section 040, "Exposure of Individuals to Concentrations of Radioactive Materials in Restricted Areas," Washington State Department of Health, 01ympia, Washington, January 31, 1991.

WAC 246-221, "Radiation Protection Standards," Section 060,

WAC 246-221. "Radiation Protection Standards," Section 290, "Appendix A - Concentrations in Air and Water Above Natural Background," Washington State Department of Health, 01ympia, Washington, January 31, 1991. 
WHC-EP-0826, Rev. 1

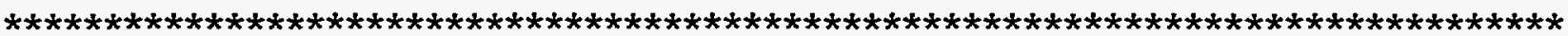

Air Regulations

40 CFR $61.92^{37}$

air emissions (except radon)

$10 \mathrm{mrem} /$ year

40 CFR $61.192^{38}$

air emissions (radon):

$20 \mathrm{pCi} / \mathrm{m}^{2} \mathrm{~s}$

WAC $173-480-040^{39}$

air emissions (except radon) (whole body):

$25 \mathrm{mrem} /$ year

air emissions (except radon) (critical organ):

$75 \mathrm{mrem} /$ year

WAC $173-480-060^{40}$

best available radionuclide control technology

WAC $246-247-040^{41}$

air emissions (whole body) (other than radon)

$25 \mathrm{mrem} /$ year

air emissions (critical organ) (not radon):

$75 \mathrm{mrem} /$ year

40 CFR 61, Subpart H, "National Emission Standards for Emissions of Radionuclides Other than Radon from Department of Energy Facilities," Section 92, U.S. Environmental Protection Agency, Washington D.C., December 15, 1989.

40 CFR 61, Subpart Q, "National Emission Standards for Radon Emissions from Department of Energy Facilities," Section 192, U.S. Environmental Protection Agency, Washington D.C., December 15, 1989.

WAC 173-480, "Ambient Air Quality Standards and Emission Limits for Radionuclides," Section 040, Washington State Department of Ecology, 01ympia, Washington, July 7, 1986.

40

WAC 173-480, "Ambient Air Quality Standards and Emission Limits for Radionuclides," Section 060, Washington State Department of Ecology, Olympia, Washington, July 7, 1986.

WAC 246-247, "Radiation Protection - Air Emissions," Section 040, Washington State Department of Ecology, 01ympia, Washington, January 31, 1991. 
WHC-EP-0826, Rev. 1

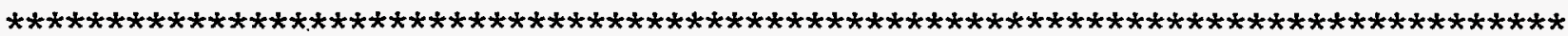
Drinking Water Regulations

40 CFR $141.11^{42}$

$\begin{array}{lll}\text { As } & 0.05 \mathrm{mg} / \mathrm{L} \\ \mathrm{Be} & 0.004 \mathrm{mg} / \mathrm{L} \\ \mathrm{Cr} & 0.05 \mathrm{mg} / \mathrm{L} \\ \mathrm{Pb} & 0.05 \mathrm{mg} / \mathrm{L} \\ \mathrm{Se} & 0.01 \mathrm{mg} / \mathrm{L} \\ \mathrm{Sb} & 0.006 \mathrm{mg} / \mathrm{L} \\ \text { Nitrate(as N) } & 10 \mathrm{mg} / \mathrm{L}\end{array}$

40 CFR 141.12

chlorinated hydrocarbons:

$0.0002 \mathrm{mg} / \mathrm{L}$ trihalomethanes:

40 CFR 141.15

$R a-226+R a-228$

alpha activity (except $R a$ and $U$ )

$5 \mathrm{pCi} / \mathrm{L}$

$15 \mathrm{pCi} / \mathrm{L}$

40 CFR 141.16

beta and photon activity $(2 \mathrm{~L} / \mathrm{d})$ :

$4 \mathrm{mrem} /$ year

$\mathrm{H}-3$ :

Sr-90:

$20,000 \mathrm{pCi} / \mathrm{L}$

$8 \mathrm{pCi} / \mathrm{L}$

Proposed change to 40 CFR $141^{43}$

$\mathrm{Ra}-226$

$\mathrm{Ra}-228$

$\mathrm{Rn}-222$

Uranium

beta and photon (excluding Ra-228)

adjusted gross alpha (excluding $R n-222, R a-226$, and $U$ )

$20 \mathrm{pCi} / \mathrm{L}$

$20 \mathrm{pCi} / \mathrm{L}$

$300 \mathrm{pCi} / \mathrm{L}$

$30 \mathrm{pCi} / \mathrm{L}$

4 mrem EDE/year

$15 \mathrm{pCi} / \mathrm{L}$

4210 CFR 141, "National Primary Drinking Water Regulations,"

Sections 11, 12, 15 and 16, U.S. Environmental Protection Agency, Washington, D.C., December 24, 1975.

43 Federal Register 5633050 (july 18, 1991) 
WAC $173-200-040^{44}$

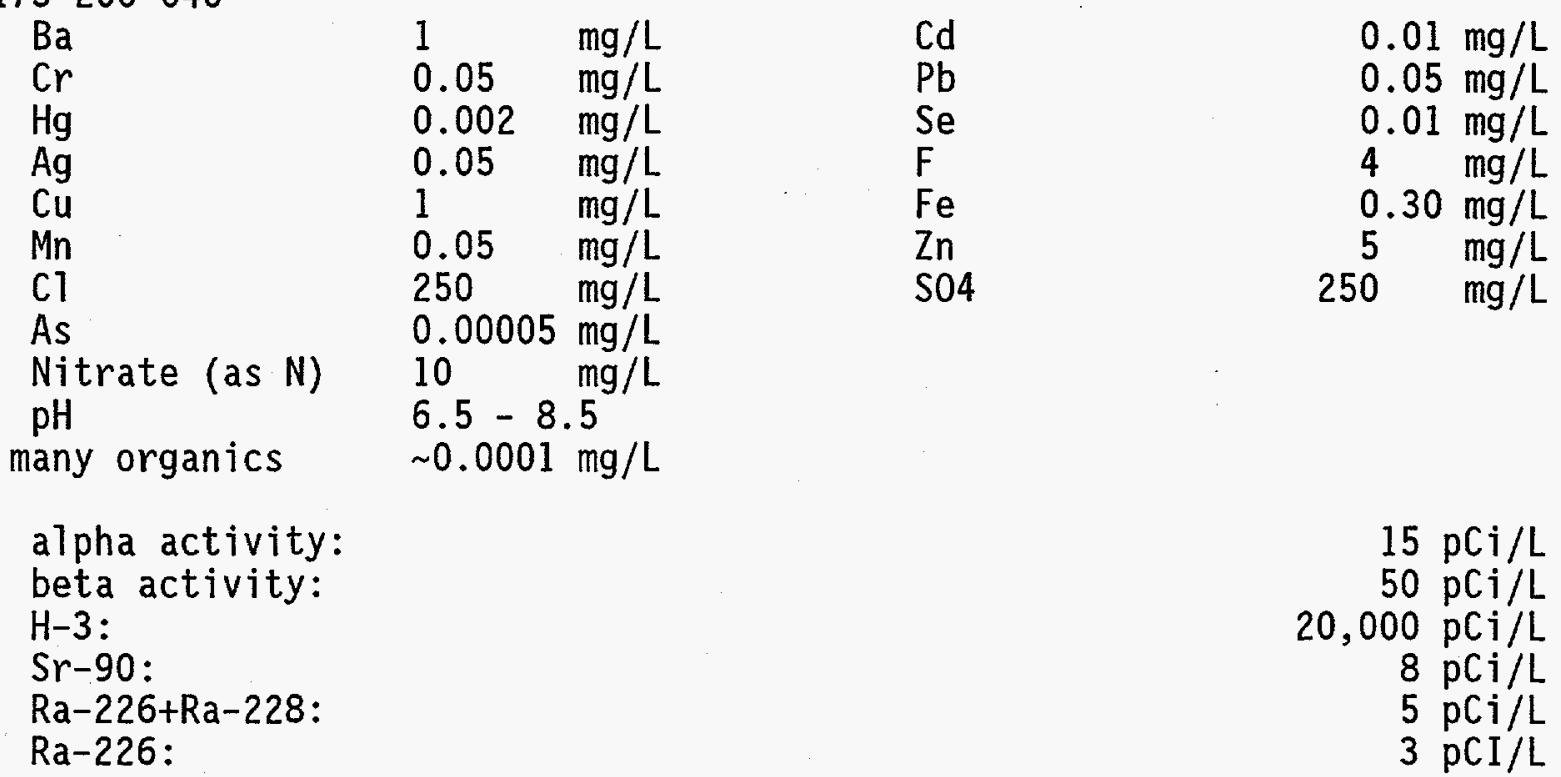

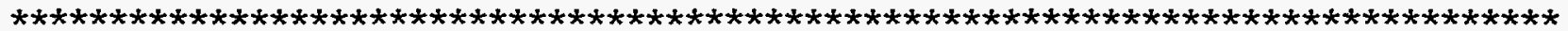

Surface Water Regulation

WAC $173-201 A^{45}$
As
0.19
$\mathrm{mg} / \mathrm{L}$
Cl
$230 \mathrm{mg} / \mathrm{L}$
$\mathrm{Cr}$
0.011
$\mathrm{mg} / \mathrm{L}$
$\mathrm{CN}$
$0.0052 \mathrm{mg} / \mathrm{L}$
$\mathrm{Hg}$
$0.000012 \mathrm{mg} / \mathrm{L}$
$\mathrm{Se}$
$0.005 \mathrm{mg} / \mathrm{L}$

Columbia River at Pasco has a mean hardness of $73 \mathrm{mg} / \mathrm{L}^{46}$

44 WAC 173-200, Water Quality Standards for Ground Waters of the State of Washington, Section 40, Washington State Department of Ecology, Olympia, Washington, December 1, 1990.

WAC 173-201A, "Water Quality Standards for Surface Waters of the State of Washington, "Washington State Department of Ecology, 07 ympia, Washington, December 22, 1992.

Site Characterization Plan, DOE/RW-0164, Volume 2, Page 3.4-16, U.S. Department of Energy, Washington, D.C., January 1988, HAVE CONSULTATION DRAFT. 
WHC-EP-0826, Rev. 1

$\begin{array}{lll}\mathrm{Cd} & 0.000865 \mathrm{mg} / \mathrm{L}(\mathrm{e} 0.7852 * \ln [\text { hardness }]-3.490)=0.00077 \mathrm{mg} / \mathrm{L} \\ \mathrm{Cu} & 0.000862 \mathrm{mg} / \mathrm{L}(\mathrm{e} 0.8545 * \ln [\text { hardness }]-1.465)=0.0078 \mathrm{mg} / \mathrm{L} \\ \mathrm{Pb} & 0.000687 \mathrm{mg} / \mathrm{L}(\mathrm{e} 1.2730 * \ln [\text { hardness }]-4.705)=0.00146 \mathrm{mg} / \mathrm{L} \\ \mathrm{Ni} & 0.00095 \mathrm{mg} / \mathrm{L}(\mathrm{e} 0.8460 * \ln [\text { hardness }]+1.1645)=0.115 \mathrm{mg} / \mathrm{L} \\ \mathrm{Zn} & 0.000891 \mathrm{mg} / \mathrm{L}(\mathrm{e} 0.8473 *] \mathrm{n}[\text { hardness }]+0.7614)=0.072 \mathrm{mg} / \mathrm{L}\end{array}$

WAC $173-201 A-05^{47}$

radionuclides 0.01 of WAC 246-221-29048 table
or EPA drinking water standards (40 CFR 141, see above) NRC Class C Limits (Concentrations in Waste) ${ }^{49}$

$\begin{array}{rlrr}\mathrm{C}-14 & 8 . \mathrm{Ci} / \mathrm{m} 3 & \mathrm{Ni}-59 & 220 . \mathrm{a} \mathrm{Ci} / \mathrm{m} 3 \\ \mathrm{Ni}-63 & 700 \mathrm{Ci} / \mathrm{m3} & \mathrm{Nb}-94 & 0.2 \mathrm{C} \mathrm{Ci} / \mathrm{m3} \\ \mathrm{Sr}-90 & 7000 . \mathrm{Ci} / \mathrm{m3} & \mathrm{I}-129 & 0.08 \mathrm{Ci} / \mathrm{m} 3 \\ \mathrm{Cs}-137 & 4600 . \mathrm{Ci} / \mathrm{m3} & & \end{array}$

alpha emitters (with half-lives greater than 5 years)

$\mathrm{Pu}-241 \quad 3500 \mathrm{nCi} / \mathrm{g} \quad \mathrm{Cm}-242$

$100 \mathrm{nCj} / \mathrm{g}$ $20000 \mathrm{nCi} / \mathrm{g}$

a only limits given are for isotope in activated metal

47 WAC 173-201A, "Water Quality Standards for Surface Waters of the State of Washington," Section 05, Washington State Department of Ecology, Olympia, Washington, December 22, 1992.

48 WAC 246-221, "Radiation Protection Standards," Section 290 , "Appendix A - Concentrations in Air and Water Above Natural Background," Washington State Department of Health, Olympia, Washington, January 31, 1991.

4910 CFR 61, "Licensing Requirements for Land Disposal of Radioactive Waste," Section 55, U.S. Nuclear Regulatory Commission, Washington, D.C., December 27, 1982 as amended May 25, 1989. 
40 CFR $261.21^{50}$ ignitability (> $1400 \mathrm{~F})$

40 CFR 261.22 corrosivity $(\mathrm{pH}<2$ or $12.5<\mathrm{pH})$

40 CFR 261.23 reactivity

40 CFR 261.24

$\begin{array}{lrrrr}\mathrm{Ar} & 5 \mathrm{mg} / \mathrm{L} & \mathrm{Ba} & 100 \mathrm{mg} / \mathrm{L} \\ \mathrm{Cd} & 1 \mathrm{mg} / \mathrm{L} & \mathrm{Cr} & 5 \mathrm{mg} / \mathrm{L} \\ \mathrm{Pb} & 5 \mathrm{mg} / \mathrm{L} & \mathrm{Hg} & 0.2 \mathrm{mg} / \mathrm{L} \\ \mathrm{Se} & 1 \mathrm{mg} / \mathrm{L} & \mathrm{Ag} & 5 & \mathrm{mg} / \mathrm{L} \\ \text { various organics } & & \end{array}$

40 CFR $268.42^{51}$

PCB

Halogenated organic compounds

WAC $173-303-90^{52}$

$\begin{array}{lllr}\mathrm{Ar} & 5 \mathrm{mg} / \mathrm{L} & \mathrm{Ba} & 100 \mathrm{mg} / \mathrm{L} \\ \mathrm{Cd} & 1 \mathrm{mg} / \mathrm{L} & \mathrm{Cr} & 5 \mathrm{mg} / \mathrm{L} \\ \mathrm{Pb} & 5 \mathrm{mg} / \mathrm{L} & \mathrm{Hg} & 0.2 \mathrm{mg} / \mathrm{L} \\ \mathrm{Se} & 1 \mathrm{mg} / \mathrm{L} & \mathrm{Ag} & 5\end{array}$

various organics

WAC $173-303-645^{53}$ (concentration in ground water)

$\begin{array}{lllll}\mathrm{As} & 0.05 \mathrm{mg} / \mathrm{L} & \mathrm{Ba} & 1 \mathrm{mg} / \mathrm{L} \\ \mathrm{Cd} & 0.01 \mathrm{mg} / \mathrm{L} & \mathrm{Cr} & * & 0.05 \mathrm{mg} / \mathrm{L} \\ \mathrm{Pb} & 0.05 \mathrm{mg} / \mathrm{L} & \mathrm{Hg} & & 0.002 \mathrm{mg} / \mathrm{L} \\ \mathrm{Se} & 0.01 \mathrm{mg} / \mathrm{L} & \mathrm{Ag} & & 0.05 \mathrm{mg} / \mathrm{L}\end{array}$

various organics

Table B.3 Conversion between Water Concentration and Dose Sections 21 through 24, U.S. Protection Agency, Washington, D.C., May 19, 1980.

WAC 173-303, "Dangerous Waste Regulations," Section 90, Washington State Department of Ecology, Olympia, washington, January, 1989.

WAC 173-303, "Dangerous Waste Regulations," Section 645, Washington State Department of Ecology, Olympia, Washington, January, 1989. 


\begin{tabular}{|c|c|c|c|}
\hline $\begin{array}{l}\text { Nucl ide } \\
\mathrm{H}-3\end{array}$ & $\begin{array}{l}\text { Limits } \\
\text { Concentration }(\mathrm{pC} i / \mathrm{L}) \\
20,000 \mathrm{a}, \mathrm{b}, \mathrm{g}, \mathrm{s} \\
30,000 \mathrm{c}\end{array}$ & Dose & $\begin{array}{l}\text { (mrem/year) } \\
0.92 \mathrm{~g}, \mathrm{~s} \\
1.38\end{array}$ \\
\hline$S r-90$ & $\begin{array}{l}8 a, b, g \\
3 c, s\end{array}$ & & $\begin{array}{l}0.82 \mathrm{~g} \\
0.31 \mathrm{~s}\end{array}$ \\
\hline Tc-99 & $\begin{array}{l}\quad 50 \mathrm{a}, \mathrm{g} \\
4,210 \\
2,000 \mathrm{c}, \mathrm{s}\end{array}$ & & $\begin{array}{l}0.05 \mathrm{~g} \\
4 . \mathrm{b} \\
1.9 \mathrm{~s}\end{array}$ \\
\hline$I-129$ & $\begin{array}{c}50 \mathrm{a} \\
19.6 \mathrm{~g} \\
2,000 \mathrm{c}, \mathrm{s}\end{array}$ & & $\begin{array}{l}10 \\
4 . \mathrm{b}, \mathrm{g} \\
1.9 \mathrm{~s}\end{array}$ \\
\hline$C s-137$ & $\begin{array}{l}50 \mathrm{a}, \mathrm{g} \\
110 \mathrm{~s} \\
200 \mathrm{c}\end{array}$ & & $\begin{array}{l}1.8 \mathrm{~g} \\
4 . \mathrm{b}, \mathrm{s} \\
7.3\end{array}$ \\
\hline$R a-226$ & $\begin{array}{l}3 a, g \\
5 b \\
0.3 c, s\end{array}$ & & $\begin{array}{l}2.4 \mathrm{~g} \\
4 . \\
0.24 \mathrm{~s}\end{array}$ \\
\hline$R a-226+R a-228$ & $\begin{array}{l}5 a, b, g \\
0.3 c, s\end{array}$ & & $\begin{array}{l}4.1 \mathrm{~g} \\
0.24 \mathrm{~s}\end{array}$ \\
\hline Th-228 & $\begin{array}{l}15 a, b, g, s \\
70 c\end{array}$ & $i$ & $\begin{array}{l}8.2 \mathrm{~g}, \mathrm{~s} \\
39 .\end{array}$ \\
\hline Th-230 & $\begin{array}{l}15 a, b, g, s \\
20 c\end{array}$ & $\because$ & $\begin{array}{l}5.8 \mathrm{~g}, \mathrm{~s} \\
7.8\end{array}$ \\
\hline Th-232 & $\begin{array}{l}15 a, b, g, s \\
20 c\end{array}$ & & $\begin{array}{l}31 . g, s \\
41 .\end{array}$ \\
\hline$U-232$ & $\begin{array}{l}15 a, b, g, s \\
300 c\end{array}$ & & $\begin{array}{l}14 . g, s \\
71 .\end{array}$ \\
\hline $\mathrm{U}-233$ & $\begin{array}{l}15 a, b, g, s \\
300 c\end{array}$ & & $\begin{array}{l}3.0 \mathrm{~g}, \mathrm{~s} \\
59 .\end{array}$ \\
\hline$U-234$ & $\begin{array}{l}15 a, b, g, s \\
300 c\end{array}$ & & $\begin{array}{l}2.8 \mathrm{~g}, \mathrm{~s} \\
57 .\end{array}$ \\
\hline$U-235$ & $\begin{array}{l}15 a, b, g, s \\
300 c\end{array}$ & & $\begin{array}{l}2.7 \mathrm{~g}, \mathrm{~s} \\
55 .\end{array}$ \\
\hline
\end{tabular}


WHC-EP-0826, Rev. 1

Table B.3 Conversion between Water Concentration and Dose (cont.)

\begin{tabular}{|c|c|c|}
\hline Nuclide & $\begin{array}{cc} & \text { Limits } \\
\text { Concentration }(p C i / L)\end{array}$ & Dose (mrem/year) \\
\hline$U-236$ & $\begin{array}{l}15 a, b, g, s \\
300 c\end{array}$ & $\begin{array}{l}2.7 \mathrm{~g}, \mathrm{~s} \\
55 .\end{array}$ \\
\hline$U-238$ & $\begin{array}{l}15 a, b, g, s \\
400 c\end{array}$ & $\begin{array}{l}2.7 \mathrm{~g}, \mathrm{~s} \\
71 .\end{array}$ \\
\hline$N p-237$ & $\begin{array}{l}15 a, b, g, s \\
30 c\end{array}$ & $\begin{array}{l}43 . g, s \\
85 .\end{array}$ \\
\hline $\mathrm{Pu}-238$ & $\begin{array}{l}15 a, b, g, s \\
50 c\end{array}$ & $\begin{array}{l}42 . g, s \\
140 .\end{array}$ \\
\hline $\mathrm{Pu}-239$ & $\begin{array}{l}15 a, b, g, s \\
50 c\end{array}$ & $\begin{array}{l}47 . \mathrm{g}, \mathrm{s} \\
160 .\end{array}$ \\
\hline $\mathrm{Pu}-240$ & $\begin{array}{l}15 a, b, g, s \\
50 c\end{array}$ & $\begin{array}{l}47 . g, s \\
160 .\end{array}$ \\
\hline $\mathrm{Pu}-241$ & $\begin{array}{l}50 a, b, g, s \\
2,000 c\end{array}$ & $\begin{array}{l}3.2 \mathrm{~g}, \mathrm{~s} \\
125 .\end{array}$ \\
\hline $\mathrm{Pu}-242$ & $\begin{array}{l}15 a, b, g, s \\
50 c\end{array}$ & $\begin{array}{l}45 . g, s \\
150 .\end{array}$ \\
\hline $\mathrm{Pu}-244$ & $\begin{array}{l}15 a, b, g, s \\
100 c\end{array}$ & $\begin{array}{l}44 . g, s \\
290 .\end{array}$ \\
\hline Am-241 & $\begin{array}{l}15 a, b, g, s \\
40 c\end{array}$ & $\begin{array}{l}49 . g, s \\
131 .\end{array}$ \\
\hline $\mathrm{Am}-242 \mathrm{~m}$ & $\begin{array}{l}50 a, b, g \\
40 c, s\end{array}$ & $\begin{array}{l}150 . \mathrm{g} \\
125 . \mathrm{S}\end{array}$ \\
\hline
\end{tabular}




$$
\text { WHC-EP-0826, Rev. } 1
$$

Table B.3 Conversion between Water Concentration and Dose (cont.)

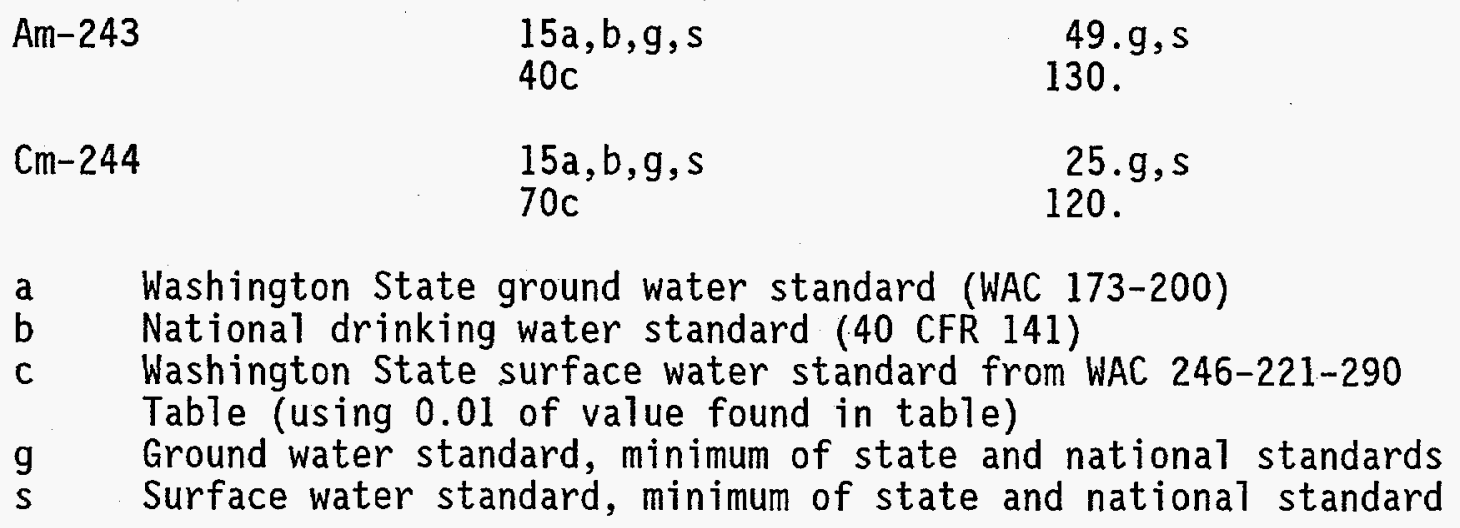


WHC-EP-0826, ReV. 1

Appendix $\mathrm{C}$

Table C.1 Previous DOE Performance Assessments

\begin{tabular}{||l|l||}
\hline \hline Performance Assessment & Status \\
\hline \hline $\begin{array}{l}\text { Radiologica] Performance Assessment } \\
\text { for the Z-Area Saltstone Disposa] } \\
\text { Facility [Savannah River Site] }\end{array}$ & $\begin{array}{l}\text { Found "technically acceptable" by } \\
\text { Peer Review Pane] }\end{array}$ \\
\hline $\begin{array}{l}\text { Performance Assessment of Grouted } \\
\text { Double-She17 Tank Waste Disposal at } \\
\text { Hanford [Hanford Site] }\end{array}$ & $\begin{array}{l}\text { Found "technically adequate" by Peer } \\
\text { Review Pane] }\end{array}$ \\
\hline $\begin{array}{l}\text { Radiologica1 Performance Assessment } \\
\text { for the E-Area Vaults Disposa] } \\
\text { Facility [Savannah River Site] }\end{array}$ & $\begin{array}{l}\text { Found "technically acceptable" by } \\
\text { Peer Review Pane7 }\end{array}$ \\
\hline $\begin{array}{l}\text { Performance Assessment of the } \\
\text { Disposal of Low-Level Waste in the } \\
\text { 218-W-5 Burial Ground [Hanford } \\
\text { Site] }\end{array}$ & $\begin{array}{l}\text { Preliminary review performed by the } \\
\text { Peer Review Panel }\end{array}$ \\
\hline
\end{tabular}

Radiological Performance Assessment for the Z-Area Saltstone Disposal Facility, WSRC-RP-92-1360, Westinghouse Savannah River company, Aiken, South Carolina, December 18, 1992.

C. T. Kincaid, J. A. Voogd, J. W. Shade, J. H. Westsik, Jr, G. A. Whyatt, M. D. Freshley, M. G. Piepho, K. A. Blanchard, K. Rhoads, and B. G. Lauzon, Performance Assessment of Grouted Double Shell Tank Waste Disposal at Hanford, WHC-SD-WM-EE-004, Rev. 0, Page 1.11, Westinghouse Hanford Company, Richland, Washington, October 1993.

Radiological Performance Assessment for the E-Area Vaults Disposal Facility, WSRC-RP-94-218, Westinghouse Savannah River Company, Aiken, South Carolina, April 15, 1994. of Low-Level Waste in the 218-W-5 Burial Ground, WHC-EP-0645 (DRAFT), Westinghouse Hanford Company, Richland, Washington, May $6,1994$. 
WHC-EP-0826, Rev. 1

\begin{tabular}{||l|l||}
\hline Performance Assessment & Status \\
\hline \hline $\begin{array}{l}\text { Performance Assessment for } \\
\text { Continuous } \\
\text { and Future Operations at Sol id Waste } \\
\text { Storage Area 6 [Oak Ridge Nationa] } \\
\text { Laboratory] }\end{array}$ & $\begin{array}{l}\text { Preliminary review performed by the } \\
\text { Peer Review Panel }\end{array}$ \\
\hline $\begin{array}{l}\text { Radiologica] Performance Assessment } \\
\text { for the Area 5 Radioactive Waste } \\
\text { Management Site at the Nevada Test } \\
\text { Site } 59\end{array}$ & Withdrawn \\
\hline $\begin{array}{l}\text { Radioactive Waste Management Complex } \\
\text { Low-Leve] Waste Radiologica] } \\
\text { Performance Assessment [Idaho } \\
\text { National Engineering Laboratory] }\end{array}$ & $\begin{array}{l}\text { Preliminary review performed by the } \\
\text { Peer Review Panel }\end{array}$ \\
\hline
\end{tabular}

58 Performance Assessment for Continuing and Future Operations Solid Waste Storage Area 6, ORNL-6783, Oak Ridge National Laboratory, Martin Marietta Energy Systems, Inc., Oak Ridge, Tennessee, Fenruary, 1994.

S. C. Magnuson, S. J. Maheras, H. D. Nguyen, A. S. Rood, J. Sing, et a1., Radiological Performance Assessment for the Area 5 Radioactive Waste Management Site at the Nevada Test Site, Idaho National Engineering Laboratory, Idaho Falls, Idaho, Revision 1.

60 Steven J. Maheras, Arthur S. Rood, Swen 0. Magnuson, MAry E. Sussman, and Rajiv N. Bhatt, Radioactive Waste Management Complex Low-Level Waste Radiological Performance Assessment, EGG-WM-8773, Idaho National Engineering Laboratory, EG\&G, Idaho Inc., Idaho Falls, Idaho, May, 1994.

$$
\mathrm{C}-2
$$


WHC-EP-0826, ReV. 1

Table C.2 Performance Objectives of Previous Performance Assessments

Z-Area, Savannah River Site S1 $^{61}$

A11 pathways:25 mrem/year

Drinking water for wel1 $100 \mathrm{~m}$ downgradient

(summed over all radionuclides): $4 \mathrm{mrem} /$ year

Inadvertent intrusion (100 years after disposal)

continuous: $100 \mathrm{mrem} /$ year

acute:500 mrem

Grout Vaults, Hanford Site ${ }^{62}$

A11 pathways $(10,000$ years $): 25 \mathrm{mrem} /$ year

Drinking Water for we $11100 \mathrm{~m}$ downgradient $(10,000$ years $): 4 \mathrm{mrem} /$ year

Inadvertent intrusion (500 years after disposal)

continuous: $100 \mathrm{mrem} /$ year

acute: 500 mrem

Air emissions (radon) $20 \mathrm{pCi} / \mathrm{m}^{2} \mathrm{~s}$

ALARA500 persons-rem/year

E-Area, Savannah River Site ${ }^{63}$

All pathways $(10,000$ years $) 25 \mathrm{mrem} /$ year

Drinking water for wel1 $100 \mathrm{~m}$ downgradient

EPA standards, using EPA prescribed methods

uranium: $20 \mathrm{~g} / \mathrm{L}$

Radon:20 $\mathrm{pCi} / \mathrm{m}^{2} \mathrm{~s}$

Inadvertent intrusion (100 years after disposal) continuous: $100 \mathrm{mrem} /$ year

acute: 500 mrem

Table C.2 Performance Objectives of Previous Performance Assessments (cont.)

Radiological Performance Assessment for the Z-Area Saltstone Disposal Facility, WSRC-RP-92-1360, Westinghouse Savannah River Company, Aiken, South Carolina, December 18, 1992.

62

C. T. Kincaid, J. A. Voogd, J. W. Shade, J. H. Westsik, Jr, G. A. Whyatt, M. d. Freshley, M. G. Piepho, K. A. Blanchard, K. Rhoads, and B. G. Lauzon, Performance Assessment of Grouted Double Shel1 Tank Waste Disposal at Hanford, WHC-SD-WM-EE-004, Rev. 0, Page 1.11 , Westinghouse Hanford Company, Richland, Washington, October 1993.

Radiological Performance Assessment for the E-Area Vaults Disposal Facility, WSRC-RP-94-218, Westinghouse Savannah River Company, Aiken, South Carolina, April 15, 1994. 
218-W-5 Burial Ground, Hanford Site ${ }^{64}$

A11 pathways $25 \mathrm{mrem} /$ year.

Drinking Water for well $100 \mathrm{~m}$ downgradient: $4 \mathrm{mrem} /$ year

Inadvertent intrusion (100 years after disposal)

continuous: $100 \mathrm{mrem} /$ year

acute: 500 mrem

Air emissions (radon) $20 \mathrm{pCi} / \mathrm{m}^{2} \mathrm{~s}$

SWSA 6, Oak Ridge National Laboratory ${ }^{65}$

A11 pathways:25 mrem/year

Drinking water for well $100 \mathrm{~m}$ downgradient

(summed over all radionuclides): 4 mrem/year

Inadvertent intrusion ( 100 years after disposal)

continuous $100 \mathrm{mrem} /$ year

acute:500 mrem

Area 5, Nevada Test Site 66

A11 pathways:25 mrem/year

Drinking water for we $11100 \mathrm{~m}$ downstream $(10,000$ years)(summed over a11 radionuclides): $4 \mathrm{mrem} /$ year

Inadvertent intrusion (100 years after disposal)

continuous: $100 \mathrm{mrem} /$ year

acute: 500 mrem

Air emissions:10 mrem/year

Table C.2 Performance Objectives of Previous Performance Assessments (cont.)

64 M.I. Wood, R. Khaleel, P.D. Rittman, A.H. Lu, S. Finfrock, R.J.

Sene, and K.J. Cantre17, Performance Assessment for the Disposal of Low-Level Waste in the 218-W-5 Burial Ground, WHC-EP-0645

(DRAFT), Westinghouse Hanford company, Richland, Washington, May 6,1994 .

65

Performance Assessment for Continuing and Future Operations Solid Waste Storage Area 6, ORNL-6783, 0ak Ridge National Laboratory, Martin Marietta Energy Systems, Inc., Oak Ridge TN, February, 1994.

S. C. Magnuson, S. J. Maheras, H. D. Nguyen, A. S. Rood, J. Sing et al., Radiological Performance Assessment for the Area 5 Radioactive Waste Management Site at the Nevada Test Site, Idaho National Engineering Laboratory, Idaho Falls, Idaho, Revision 1. 


$$
\text { WHC-EP-0826, Rev. } 1
$$

RWMC, Idaho National Engineering Laboratory ${ }^{67}$

A11 pathways (but air): $25 \mathrm{mrem} /$ year

A11 pathways (air only):10 mrem/year

Drinking Water for well $100 \mathrm{~m}$ downstream:4 mrem/year (alpha emitters other then $U$ and $R n) 15 \mathrm{pCi} / \mathrm{L}$

Inadvertent intrusion (100 years after disposal) continuous: $100 \mathrm{mrem} /$ year acute: $500 \mathrm{mrem}$

(radon included in inadvertent intrusion)

67. Steven J. Maheras, Arthur S. Rood, Swen 0. Magnuson, MAry E. Sussman, and Rajiv N. Bhatt, Radioactive Waste Management Complex Low-Level Waste Radiological Performance Assessment, EGG-WM-8773, Idaho National Engineering Laboratory, EG\&G, Idaho Inc., Idaho Falls, Idaho, May, 1994.

$$
c-5
$$




\section{Appendix D}

\section{Table D.1 Chemical Ground Water Limits}

Chemical concentration limits for ground water protection are determined in the same way as for radionuclide limits. Although organic compounds are assumed to be destroyed during the vitrification process, some organic limits are included here in case organic compounds are made part of the structure of the disposal facility.

$\begin{array}{lcl}\text { Chemical } & \text { Limit (mg/L) } & \text { Source of Limita } \\ \text { Antimony } & 0.006 & \text { Fr-57 } \\ \text { Arsenic } & 0.00005 & \text { WAC, carcinogen } \\ \text { Barium } & 1.004 & \text { WAC \& EPA } \\ \text { Bery17ium } & 0.004 & \text { FR-57 } \\ \text { Cadmium } & 0.01 & \text { WAC } \\ \text { Chlorine } & 250 . & \text { WAC } \\ \text { Chromium } & 0.05 & \text { WAC \& EPA } \\ \text { Cyanide } & 0.2 & \text { FR-57 } \\ \text { Copper } & 1 . & \text { WAC } \\ \text { Fluorine } & 4 . & \text { WAC \& EPA } \\ \text { Iron } & 0.30 & \text { WAC } \\ \text { Lead } & 0.05 & \text { WAC \& EPA } \\ \text { Manganese } & 0.05 & \text { WAC \& EPA } \\ \text { Mercury } & 0.002 & \text { WAC \& EPA } \\ \text { Nitrate (as N) } & 10 . & \text { WAC \& EPA } \\ \text { Nitrite (as N) } & 1 . & \text { WAC \& EPA } \\ \text { Nitrate + Nitrite } & 10 . & \text { WAC \& EPA } \\ \text { Selenium } & 0.01 & \text { WAC : } \\ \text { Sulfates } & 250 . & \text { WAC } \\ \text { Silver } & 0.05 & \text { WAC } \\ \text { Zinc } & 5 . & \\ & \text { EPA } \\ \text { Chlorinated } & 0.0002 & \text { EPA } \\ \text { hydrocarbons } & 0.10 & \text { WAC } \\ \text { Trihalomethanes } & 0.0001 \text { to } & \\ \text { Organic carcinogens } & 0.030 & \end{array}$

a

WAC: State of Washington regulation on ground water (WAC 173-200)

EPA: National drinking water standard (40 CFR 141)

FR-57: 57 FR 31838 (7/17/92) effective 1/17/94, amendment to 40 CFR 141 . 


\section{Table D.2 Chemical Surface Water Limits}

Chemical concentration limits for surface water protection are determined in the same way as for radionuclide limits. Although organic compounds are assumed to be destroyed during the verification process, some organic 7 imits are included here in case organic compounds are made part of the engineered structure.

In those cases in which the Washington State limit is expressed in terms of hardness, a hardness value of $73 \mathrm{mg} / \mathrm{L}$ is used which is the mean value found at Pasco, Washington, just downstream of the Hanford site.

$\begin{array}{lll}\text { Chemical } & \text { Limit }(\mathrm{mg} / \mathrm{L}) & \text { Source of Limit } \\ \text { Antimony } & 0.006 & \text { FR-57 } \\ \text { Arsenic } & 0.19 & \text { WAC } \\ \text { Barium } & 1.004 & \text { EPA } \\ \text { Beryllium } & 0.004 & \text { FR-57 } \\ \text { Cadmium } & 0.00077 & \text { WAC } \\ \text { Chlorine } & 230 . & \text { WAC } \\ \text { Chromium } & 0.011 & \text { WAC } \\ \text { Copper } & 0.0078 & \text { WAC } \\ \text { Cyanide (CN) } & 0.052 & \text { WAC } \\ \text { Fluorine } & 4 . & \text { EPA } \\ \text { Lead } & 0.00145 & \text { WAC } \\ \text { Mercury } & 0.000014 & \text { WAC } \\ \text { Nickel } & 0.0115 & \text { WAC } \\ \text { Nitrate (as N) } & 10 . & \text { EPA } \\ \text { Nitrite (as N) } & 1 . & \text { EPA } \\ \text { Nitrate + Nitrite } & 10 . & \text { EPA } \\ \text { Selenium } & 0.005 & \text { WAC } \\ \text { Zinc } & 0.072 & \text { WAC } \\ & & \text { EPA } \\ \text { Chlorinated } & 0.0002 & \\ \text { hydrocarbons } & & \text { EPA } \\ \text { Trihalomethanes } & 0.10 & \text { WAC } \\ \text { Organic carcinogens } & 0.00001 \text { to } & \\ & 0.030 & \end{array}$

a WAC: $\quad$ State of Washington regulation on surface water EPA: $\quad$ National drinking water standard

FR-57: $\quad 57$ FR $31838(7 / 17 / 92)$ effective $1 / 17 / 94$, amendment to 40 CFR 141 . 
WHC-EP-0826

Rev. 1

\section{DISTRIBUTION}

Number of copies

\section{ONSITE .}

13
F. M. Mann (10) WHC Central Files

OSTI (2)
HO-36

L8-04

L8-07 


\section{RELEASE AUTHORIZATION}

Document Number: WHC-EP-0826, Rev. 1

Document Title: Performance Objectives of the Tank Waste Remediation

Systems Low-Level Waste Disposal Program

Release Date: $\quad 07 / 21 / 95$

This document was reviewed following the procedures described in WHC-CM-3-4 and is:

APPROVED FOR PUBLIC RELEASE

WHC Information Release Administration Specialist:

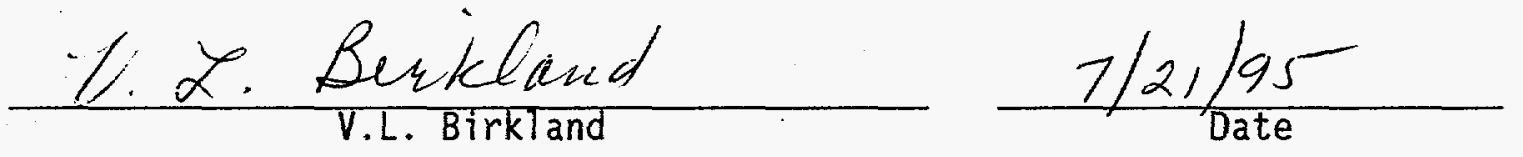

